Article

\title{
The Race for Evolutionary Success
}

\section{Bruce Tonn $^{1, *}$ and Dorian Stiefel ${ }^{2}$}

1 Department of Political Science, University of Tennessee-Knoxville, McClung Tower, Room 1018, Knoxville, TN 37996, USA

2 Department of Political Science, University of Tennessee-Knoxville, McClung Tower, Room 1001, Knoxville, TN 37996, USA; E-Mail: dori@utk.edu

* Author to whom correspondence should be addressed; E-Mail: btonn@utk.edu; Tel.: +1-865-974-7041; Fax: +1-865-974-7037.

Received: 4 July 2012; in revised form: 25 July 2012 / Accepted: 8 August 2012 / Published: 14 August 2012

\begin{abstract}
The Earth appears to be at the beginning of sixth massive species extinction. This paper balances a review of the forces threatening species survival with a comprehensive scan of factors that could act as counterweights. These factors could lead to four types of evolution — cultural, regulatory, ecological, and technological — that could individually or in combination avert massive species extinction if humans implement solutions faster than new problems arise. Implications and future research opportunities are also explored.
\end{abstract}

Keywords: environmental scanning; extinction; evolution; cultural evolution; behavioral evolution; regulatory evolution; policy evolution; ecological evolution; biological evolution; technological evolution

\section{Introduction}

Is the Earth in the initial throes of a sixth massive species extinction event? Humans have been implicated in species extinction since before the agricultural revolution [1,2] and research now suggests that the worldwide species extinction rate is much higher than the natural rate $[3,4]$. Factors that lead to species extinction are well known and include: over-exploitation, habitat loss, invasive species, pollution, disease, and climate change [5,6]. Unabated, these forces could lead to the extinction of $75 \%$ of species on Earth, the threshold for a massive extinction of species, 
between 300 and 2200 years from now [7]. Uncertainty about the causes, probability, and timing of an extinction event notwithstanding, it can be argued that humanity is not meeting its ethical and moral obligations to prevent species extinction [8-11].

We focus on all types of species extinction, though human extinction is also a possibility. Most species become extinct as a result of evolution or catastrophe, as either can lead to circumstances in which the species cannot live or reproduce. For example, extinction of the endemic birds of Guam followed the accidental introduction of brown tree snakes [12]. Humans are a robust species, so most scenarios about human extinction involve a precipitous decrease in the human population in which a few humans survive. In fact, completely eliminating those few remaining humans is always an unlikely scenario though Diamond [13] describes historic, failed civilizations and makes the case that over harvesting renewable resources, climate change, fewer friends, more enemies, and institutional cultural failure lead to civilization collapse. He urges us to address issues such as the destruction of natural resources and overpopulation.

Regardless, humans are generally resilient and inventive. For example, Tonn and MacGregor [14] describe a scenario in which a series of global catastrophes lead to a rapid decrease in human population. Societies become Balkanized; the previous 'Haves' retreat to enclaves and destroy the technological infrastructures outside of the enclaves that could be used by the 'Have-nots' to threaten the enclaves. Over time, the enclaves themselves perish because inhabitants outlive their capacity for fertility and human cloning fails. Resources available to the 'Have-nots' continue to collapse. A series of natural disasters then befall the Earth and the remaining humans. Due to rapid cooling and the oxidation of suddenly exposed rock from falling sea levels, the level of oxygen in the atmosphere drops below the level needed to sustain human life. The last humans asphyxiate. This scenario posits a long chain of unlikely events, yet this series of events — in any order — could plausibly lead to a major decline in population.

The question is whether humans have the capacity to adapt in timely and effective manners. Even Diamond [13] agrees that we have reasons to hope: (1) Humans can change their behavior and solve most of these problems, especially the environmental problems because we are the cause; (2) More and people are thinking about the environment more. We just have to choose long-term planning and rethink our core values [13]. Moreover, "our self-interested culture differs in one important respect from those of the past; its effects can be manipulated in ways the others could not. Our sophisticated political, economic, legal, and social institutions allow us to channel and harness our self interest" [15].

Is a sixth massive species extinction preventable? This article explores evolutionary trends in culture, regulation, ecology, and technology that could contravene the extinction factors listed above. It is tempting to cite these positive trends as we become complacent and decide that additional work and urgency are unnecessary. We found many positive trends, but the ultimate challenge is still to do enough of the right things at the right time so that we are implementing solutions faster than new problems arise. We wrote this article to encourage discussion as well as prompt, effective, and sustained action.

The next section presents our environmental scanning analytical framework. The balance of the paper presents the results of our environmental scan, a series of positive trends that could prevent massive species extinction thus allowing us to win the race for evolutionary success. 


\section{Environmental Scanning Analytical Framework}

We acknowledge that there are many paths to extinction, which is why many evolution and extinction scenarios end with massive species extinction [16-21]. Though paths vary depending upon the elements involved - energy consumption, land development, economic production, climate change, etc. - the ultimate predicted outcome for species is usually starvation and then extinction.

To identify the paths to extinction and to identify the potential for various types of countervailing trends, we used the environmental scanning framework methodology developed by Tonn [22]. The foundation of the methodology is a systems model of the context under study. The resulting model, presented in Figure 1, encompasses seven major factors that threaten species survival, including energy consumption, land development, economic production, climate change, etc.; and seven pathways to species extinction, including unsustainable predation, habitat loss, and adaptation failure.

Figure 1. Scanning framework with categories for evolutionary successes.

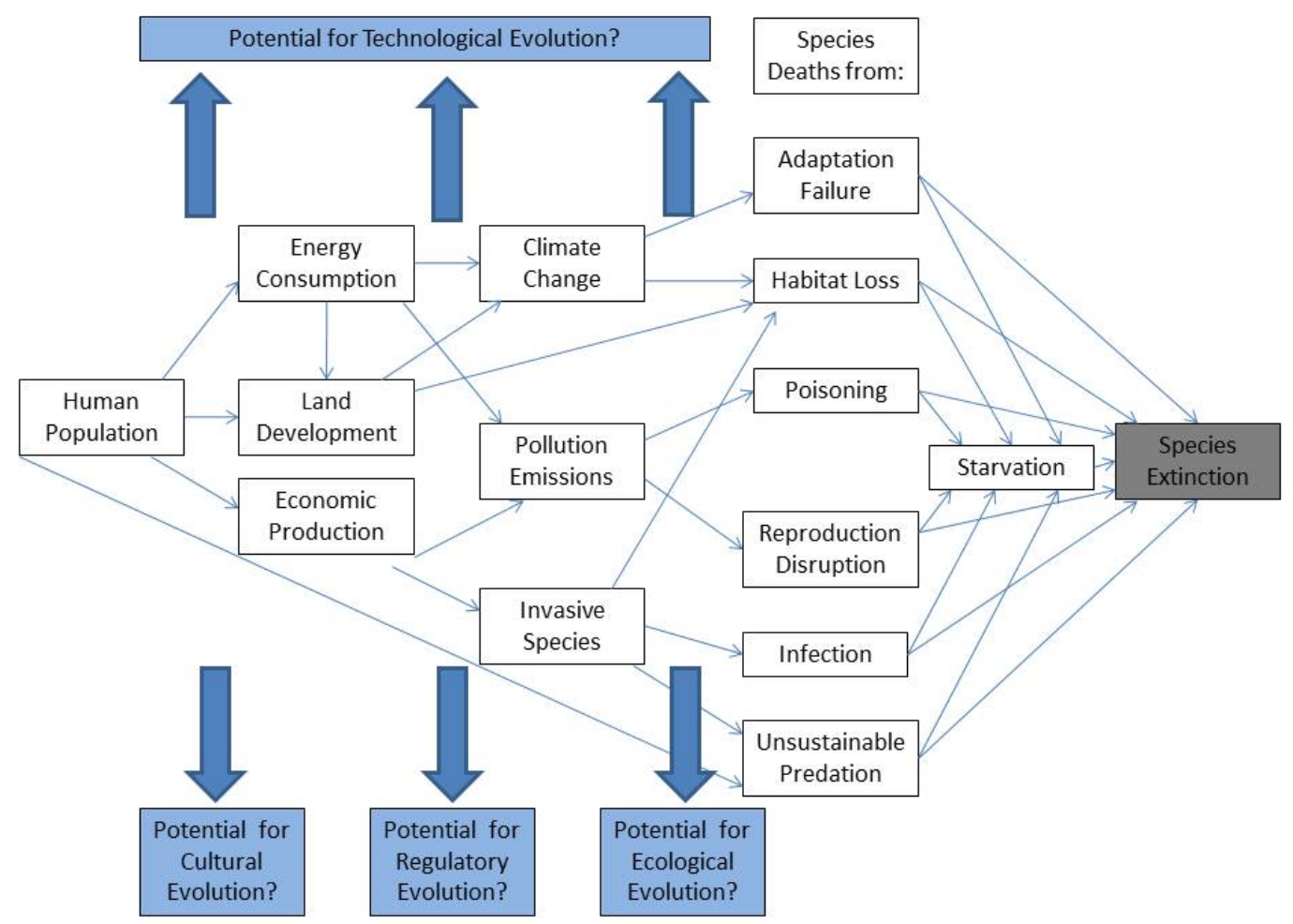

As indicated in Figure 1, we posit that cultural, regulatory, ecological, and technological evolution can disrupt the paths to species extinction in a variety of ways. The next section presents trends in each of these areas that could be the seeds of evolutionary changes necessary to prevent a devastating extinction event.

\section{Results}

For each potential evolution, we describe the forces that could lead to species extinction, which we term threats. We also note the positive trends that could lead to evolutionary successes. We end each 
section with examples of evolutionary success occurring throughout the world. Ultimately, each evolution has the potential to intercede in the path to extinction and lead us to evolutionary success.

However, the forces that could lead to species extinction and the related solutions are all constrained by time. Choices have implications that stretch over decades. Sometimes the time frame is set (e.g., terms for elected officials) and sometimes we must choose the time frame (e.g., deadlines for implementing environmental remediation). Time frames for actual events and problems are different than the time frames for governments and other organizations that are accountable for the solution. Thus, we must consciously match the time frame with the activity, especially when a problem could become a catastrophe before the solution can be invented or fully implemented [23].

At the same time, we must remain aware of individual and social capacities for considering time. Boniecki concluded that our individual time horizon is fewer than fifteen years and that public planning is more likely to achieve buy-in if the time horizon is fewer than five years [24]. Similarly, Tonn et al. found that most individuals' abilities to imagine the future goes 'dark' at the ten-year horizon [25]. We understand that high-level nuclear waste requires special care for a million years [26], yet only a few countries have disposal plans, much less actual disposal programs [27]. Thus, the time frame over which problems must be considered and solved may exceed our inherent time frame for considering them. This inherent limitation underlies all of the threats and trends we present below.

\subsection{Cultural Evolution}

Cultural evolution, which includes human behavioral evolution, refers to the ongoing changes over time in one or more inherited traits of particular societies, groups, and individuals [28].

Threats to cultural evolution. The impacts of human behavior upon the environment and, more specifically, species extinction, are substantial and widespread. Due in part to unprecedented growth in both population and affluence, humans have appropriated much of the land mass and fresh water of the Earth for their own purposes. Our actions have changed between one-third and one-half of Earth's surface and we use more than half of all accessible surface fresh water [29].

Land development for human settlements and agriculture has destroyed vast tracts of wildlife habitat and has effectively limited species range and abundance [30]. Consumption of fossil fuels adds to the destruction of habitat, emits harmful pollutants, and is the leading cause of climate change [31]. Production and consumption of other goods and services contributes to these threats to species survival. We have exploited animals as varied as whales, turtles, "siskowet" lake trout, and kangaroos [32].

Trends leading toward cultural evolution. Our environmental scan identified several major trends that could result in culture becoming less of a threat to species survival. One important trend is urbanization. Urbanization, defined as more people living in denser urban environments, is increasing worldwide [33]. Over $80 \%$ of Americans now live in urban areas. Recently, for the first time in history, the urban population worldwide exceeded $50 \%$. Viewed from a long-term perspective, this is a positive trend because it means that humans may be congregating in more efficient and spatially-limited settlements rather than continuing to disrupt new habitats by spreading out. The challenge to this trend is that there is some evidence that increased human density can be related to decreased quality of life or satisfaction, or at least the perception of decreased quality of life or 
satisfaction [34,35]. Moreover, urban populations require food and energy that are usually provided by external systems with a lengthy distribution cycle. Over time and with concerted effort, these can be offset with local food and energy production, both of which require changes in infrastructure and thinking.

Trends related to sustainable development in less dense settlements are also positive. For example, the Global Ecovillage Network is increasing the number of member-sustainable communities and the number of initiatives. The Global Ecovillage Network began just two decades ago and now connects more than 600 ecovillages [36]. This is an example of effective and sustained action over time because by 2000 they had consultative status with the United Nations Economic and Social Council; today the network includes thousands of villages around the world ranging from urban projects to permaculture projects [37]. The challenge is that those ecovillages represent a tiny fraction of the total communities in the world. Increasing the numbers of communities and total participants will require additional outreach and clear explication of the benefits, though we may also be at the point where those principles must be incorporated into existing villages and neighborhoods.

Another significant trend is that overall human population growth rates are decreasing, thus we may have fewer humans in the future and could begin to see a decline in anthropogenic effects. In many countries, mostly developed, fertility rates are below replacement levels. Figure 2 presents fertility rates and hotspots worldwide and suggests that population pressures are declining in most of the world's ecological hot spots, such as in the coastal regions of North and South America, the Amazonian region, and around the Mediterranean Sea. Population pressures remain in Southeast Asia, Central America, and in portions of Africa. However, demographic and economic development forecasts suggest that fertility rates will continue to decline over the next century, with especially significant declines in developing countries [38].

Trends in urbanization and increasing densities match an international trend towards increasing concern about the Earth's environment [39]. Increasing concern about the Earth's environment may lead to actual changes in behavior such as decreased development or decreased demand for material goods and thus decreased production and energy use. While in the near-term it appears that energy use will continue to increase, trends towards renewable energy resources and energy efficiency are unmistakable and hold much promise for the mid- to long-term. Lastly, the growing aging population [40], another major worldwide trend, likes to travel and that leads to an incentive towards preserving ecological hotspots for tourists $[41,42]$. 
Figure 2. World Population Density and the 25 Biodiversity Hotspots. World population density (1995) and the 25 biodiversity hotpots (outlined in red, numbered), and three major tropical wilderness areas (outlined in green, lettered). Hotspots: (1) Tropical Andes; (2) Mesoamerica; (3) Caribbean; (4) Atlantic Forest Region; 5) Chocó-Darién-Western Ecuador; (6) Brazilian Cerrado; (7) Central Chile; (8) California Floristic Province; (9) Madagascar; (10) Eastern Arc Mountains and Coastal Forests of Tanzania and Kenya; (11) West African Forests; (12) Cape Floristic Region; (13) Succulent Karoo; (14) Mediterranean Basin; (15) Caucasus; (16) Sundaland; (17) Wallacea; (18) Philippines; (19) Indo-Burma; (20) Mountains of South-Central China; (21) Western Ghats and Sri Lanka; (22) Southwest Australia; (23) New Caledonia; (24) New Zealand; and (25) Polynesia and Micronesia. Major tropical wilderness areas: (A) Upper Amazonia and Guyana Shield; (B) Congo River Basin; and (C) New Guinea and Melanesian Islands. Reprinted by permission from [42].

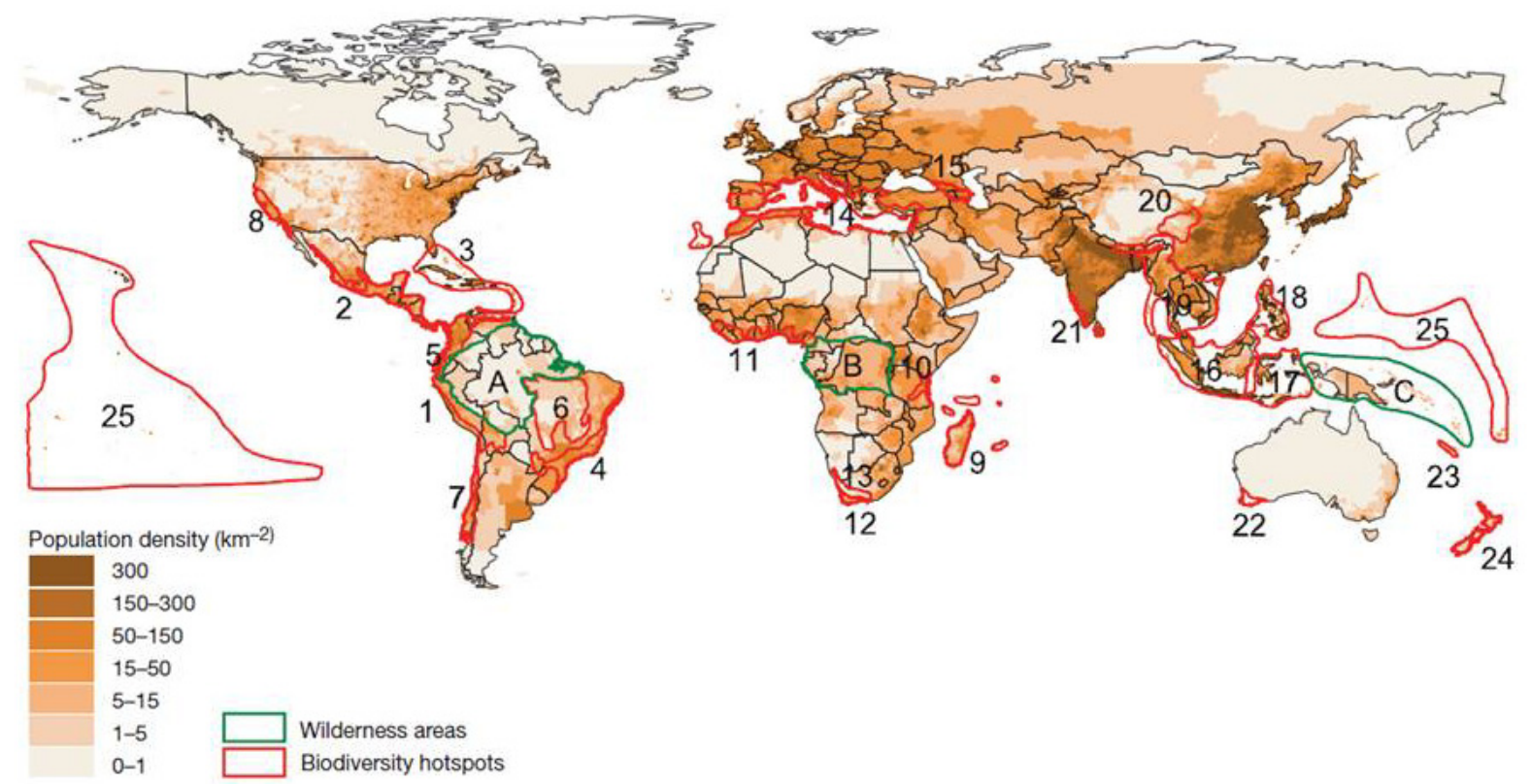

Challenges of cultural evolution. One fundamental challenge with respect to cultural evolution is that culture evolves organically. It cannot be imposed from the top down. On the one hand, the manner in which individuals and communities worldwide have embraced the concept of sustainability can be considered a sea change in social values. Because most views on sustainability incorporate concerns for biodiversity, species protection, and a host of other-environmentally related values, we could argue that cultural evolution is well underway. On the other hand, culture provides stability for individuals, families, and communities. Culture provides structure and predictability with respect to social and economic interactions. So, while individuals could, theoretically, change their behaviors tomorrow, practically, behavioral change is much more difficult to carry through because of the wide range of cultural influences that act to constrain behavior. For example, Marglin argues that market cultures in the Third World undermine traditional communities to produce a cultural focus on self-interest. He suggests that finding the balance between self-interest and duty to others may rely on finding an approach other than market cultures and traditional economic models [43]. 
Time is needed for individuals to imagine behavioral and cultural change and test things out. Culture will evolve as the changes become more accepted and worked into the social fabric of everyday life.

\subsection{Regulatory Evolution}

Regulatory evolution, which includes policy evolution, refers to the ongoing changes over time in one or more characteristics of particular regulations or policies. There are three themes to regulatory evolution. First, interests may desire regulatory evolution but there may not be money to support it. Second, there may be a missing institutional or structural piece [44] for advocating or implementing policy evolution. Third, the relationship between the science and policy endeavors may not be developed enough to effectively transmit information and ideas [45].

Threats to regulatory evolution. The typical threats to regulations or policies are insufficient participation in the planning process; poor implementation strategies; inadequacy of qualified staff; and a piecemeal approach to the planning process [46]. For example, in northern Tanzania, three out of four households surveyed deemed their planning process a failure and cited the preceding reasons, among others [46].

In the United States, species protection is hampered by inadequate funding for ecological research; lack of coordination across federal agencies and political jurisdictions; land use planning that is insensitive to species concerns; and conflicts between species protection on one hand and private property rights and economic development on the other $[47,48]$.

The time frame challenge to regulatory evolution is huge. Often the time frame for a particular elected or appointed official's term is drastically shorter than the time frame of the problem they are accountable for solving (e.g., high-level nuclear waste disposal or ocean acidification). Thus, even as a human lifetime is too short a time frame, often problems and solutions are only considered in the context of a term of office. Similarly, budget terms are also short. The money to solve problems is often appropriated in one- to five-year increments even for problems that require centuries of sustained effort backed by the requisite financial resources.

Trends leading toward regulatory evolution. The over-arching trend in this area is that the world has acknowledged a need for action. The Intergovernmental Panel on Climate Change (IPCC) is an excellent example of this [49]. Periodically, the IPCC reviews, distills and synthesizes what is known about climate change and the implications for humanity. It provides its findings through assessment reports that now have global impacts. Still, to temper this positive development, despite the fact that the IPCC has existed since 1988 and has published many reports, the global mean temperature increase since 1990 is $0.33{ }^{\circ} \mathrm{C}$ [50]. As with any human institution, the IPCC is a work in progress. Critics list the following issues with the IPCC: a hierarchical knowledge structure with the social sciences following the natural sciences; an insufficient number of developing country experts; and reliance on grey literature, among other complaints [51].

The IPCC is not the only active and influential international development. Participants in the 1992 Convention on Biological Diversity created a strategy for addressing the global decline in biodiversity. The 2002 World Summit on Sustainable Development members agreed to conservation targets. The International Union for Conservation of Nature's Countdown 2010 program helps monitor 
progress toward stemming biodiversity loss [52]. Recently, scientists and policymakers proposed the Intergovernmental Platform on Biodiversity and Ecosystem Services (IPBES) that would function like the Intergovernmental Panel on Climate Change (IPCC) to figure out what policymakers need; assess the state of the knowledge; support policy formulation and implementation; and prioritize capacity-building needs [53].

Lastly, the number of United Nations Educational, Scientific and Cultural Organization (UNESCO) Man and the Biosphere reserves is increasing: since the program was founded in 1970 the number of sites has grown to 564 sites in 109 countries [54]. This is another example of effective and sustained action over time because the organization steadily established more sites in more countries across four decades. True, critics could allege that they could have grown more sites more quickly, but growth has to be balanced with quality.

The rise of international collaboration to protect biodiversity is complemented by the emergence of an active and influential non-governmental sector [55] devoted to environmental concerns. In the United States, there is a trend towards an increase in nonprofits by number and as a percentage of Gross Domestic Product (GDP) [56]. Many nonprofits such as the Sierra Club, Environmental Defense, and the World Wildlife Fund work to protect the environment and biodiversity. Other nonprofits, such as Conservation International and The Nature Conservancy, acquire and protect land that has high ecological value.

There are also major trends that are impacting the environmental-friendliness of business. For example, the International Organization for Standardization (ISO) promulgates environmental, climate change, and greenhouse gas management standards [57]. ISO-type standards and green, water-content, and carbon labeling on consumer products [58] could lead to vetted, prioritized information for policymakers as well as significant changes at the individual and organizational behavioral levels.

These efforts are matched by improved environmental management strategies and federal-to-local collaboration designed to protect species [59]. Policymakers can create and fund programs to manipulate evolutionary processes such as selection, variation, and gene flow and that could allow us to preserve threatened species, combat pest species, or reduce undesirable evolutionary changes [60]. Policymakers also can implement change through fund allocations. In one study, allocating funds based on the ecological stability of ecoregions could reduce "biodiversity loss of terrestrial endemic species from protected areas due to climate change by $22 \%$ for the period of 2002-2052, when compared to allocations that do not consider climate change" [61].

Some of these opportunities have become real-life examples. The African Wildlife Foundation's (AWF) African Heartland Program addresses biodiversity conservation targets while simultaneously seeking to improve local livelihoods [62]. Others have learned from natural resource planning and management exercises that it is important to involve key individuals in the learning process; to be clear about the role of researchers; and to remember that local resource users are also key decision makers [63].

In another example, researchers designing a regional-scale conservation plan had insufficient data about habitat availability, distribution, and abundance of seabream species. Through participatory workshops, they solicited data from marine resource users, managers, and scientists and used the answers to fill in missing data and to verify current data and findings [64]. 
Challenges of regulatory evolution. Unlike culture, policies can be changed from the top-down and can be changed at any time. Unfortunately, there are numerous challenges to regulatory evolution. The time frame challenge to regulatory evolution is that elected and bureaucratic officials operate on a time frame that is different than the onset or advancement of the problem. Maybe even more importantly, policy-makers typically rely on economic analytical tools to help them make decisions. These tools generally discount future benefits of prospective policies, thus making it difficult to justify expensive policies whose benefits will largely benefit future generations. Culture also impacts policy-making, wherein debates about policy alternatives often disintegrate into power struggles between historical antagonists who are driven by ancient memes rather than rational discourse.

Heuristics and biases challenge regulatory evolution. Humans often make decisions based on the most easily accessible relevant examples - the availability bias [65]. The cognitive resistance to science [66] and the suppression of science [67] are based respectively in the ideas that we resist scientific information that is different than our intuition and that we suppress or reframe information that is politically or socially inconvenience. The bias to optimism [68] is our human tendency to overestimate the future probability of positive events and underestimate the future probability of negative events.

Together, these heuristics and biases afflict citizens and policymakers alike. For example, the North Carolina legislature just sent a bill to the Governor Perdue that would prohibit North Carolina state agencies from considering accelerated sea level rise until 2016 [69], despite significant scientific evidence that sea level rise must be a factor in public planning now. Extraordinary efforts by sustainability researchers and others to imagine, articulate, and create novel and acceptable win-win solutions must be seen as a core component of regulatory evolution.

\subsection{Ecological Evolution}

Ecological evolution, which includes biological evolution, refers to the ongoing changes over time in one or more inherited traits of individual species and/or the ecosystems within which they exist.

Threats to ecological evolution. The threats to ecological evolution are numerous. Changes in the climate lead to extreme weather and climate events, which in turn require increased disaster preparation and overall resilience [70]. In fact, global climate change is a factor in the increase in natural disasters [71], a critical disrupter to ecological evolution [72,73], and demands scientific and popular attention.

Tropical forests continue to be developed [74] even as extinction of species continues [75] and most ocean fish are over-harvested [31]. Invasive species are increasingly causing great economic and ecological harm yet, as in the example of trout and red deer in Argentina and Chile, some are protected for profit [76]. One especially interesting threat is the relationship between gene flow, mutation, and sexual reproduction that leads to local genetic variation and then local adaptation. It turns out that this cycle may reduce local adaptation by exchanging maladapted for adapted genes [77].

Trends leading toward ecological evolution. Are there any indications that species and/or ecological evolution could act to ameliorate the forces of species extinction? It is clear that some species are already evolving due to various environmental pressures. Microbes are emerging and re-emerging [78]; bacteria are evolving resistance to antibiotics [79]; and insects are evolving 
resistance to insecticides [80]. Other examples include animals that are adjusting to changing habitats such as sand gobies or the three-spined stickleback [81]; resistance to infections, poisons, and endocrine disruptors; the use of predation defenses such as those we see in aphids and or the inducible defenses of the phytoplankton genus [82]; and the evolution and protection mechanisms in microbes [78].

Periods of increased biodiversity have been characterized by the punctuated equilibrium model wherein stasis is the norm and is only rarely interrupted by splits [83]. The spread of invasive species, while damaging in the near-term, may lead to a new explosion of biodiversity tested by the rigors of climate change. Thus, there is some hope that enough species will be able to evolve fast enough on their own to outpace the combined set of threats to their existence posited in Figure 1.

Some aspects of "directed" ecological evolution already exist in the world. Treatments exist to "slow the evolution of resistance by weeds, pests, and pathogens" and there are now breeding programs that maximize crop yield or quality [84]. Researchers have noticed that some species are struggling while others thrive and are studying the variations in order to figure out why [85]. For example, studying phenotypic plasticity, plants' approach to global change may prompt ideas related to other species' evolution [86].

Species adaptation may become a factor in successfully responding to changing climates [87]. Others suggest that we must move endangered species as the only way to maintain some climate-endangered species in the wild [88]. Regardless, local adaptation must be a factor as we consider the ecological effects of climate change.

To this point, we have characterized climate change as a threat. In this instance, climate change is an opportunity: It turns out that climate change can highlight evolutionary resilience in which local environments retain the high levels of genetic variation that are likely to be necessary given climate change [89]. As they anticipate biodiversity changes related to climate change, researchers seek to determine the extent of species' natural resilience and have already found that the capacity to cope depends on both "intrinsic factors (species biology, genetic diversity) and extrinsic factors (rate, magnitude, and nature of climatic change)" [90].

Challenges of ecological evolution. There are two key challenges of the ecological evolution we describe. First, humans are aware of the issues and the impacts yet we continue to over-harvest species even as we continue to introduce invasive species. Second, ecological evolution is challenged by the still-unknown effects of climate change and extreme events. We can address these two challenges to ecological evolution or watch them emerge and see what happens.

The time frame challenges to ecological evolution are that individual species evolutions are happening faster than we can study them and environmental conditions may be changing more quickly than species adaption capabilities. Worse, we tend to study evolutions by species or habitat, which means we are missing the big picture of what is happening across species and habitats. Thus, ecological evolution can only be effective to the extent that researchers learn quickly enough complex ecological systems in order to give the regulatory world time to make informed decisions.

\subsection{Technological Evolution}

Technological evolution refers to changes over time in one or more inherited characteristics of a particular technology or suite of technologies. Ultimately, triumphs of technology may overcome the 
threats already noted above and those mentioned next - we may be able to outthink the problems in the other realms and implement technological solutions.

Threats to technological evolution. A conventional argument is that technology is at the root of most if not the majority of factors that threaten species survival. Advances in agricultural technology led to widespread land conversions. The Industrial Revolution led to our current fossil-fuels-dependent economies and all of the environmental externalities associated with it. The invention of the automobile, highways, electricity production and transmission, and advanced telecommunications enabled sprawl development resulting in negative impacts to land, air, and water.

Consumption-based societies engender natural-resource-consuming and pollution-emitting industries. Technological fixes, such as the synthetic pesticide dichlorodiphenyltrichloroethane (DDT), often have unintended consequences [91]. There are international conversations about geo-engineering to repair some of the atmospheric damage caused by greenhouse gases [92], but scientists disagree about the effects and cite concerns about effects on regional climate, continued ocean acidification, and human error, among others [93,94]. Humanity would have to be facing extremely dire consequences to risk geo-engineering the planet.

Trends leading toward technological evolution. If one adopts Arthur's theory that new technologies evolve in part from the combination of new and existing technologies [95], then the opportunities for technological evolution are essentially limitless. The question is whether advances in information technology, biotechnology, nanotechnology and cognitive technologies [96-98], either individually or in combination [99], will lead to reduced or increased threats to species over time.

The world may be leaving the age of centralized and dirty technologies and production. Technologists are already learning how to make items smaller, stronger, smarter, and cleaner [100]. We are also learning how to improve recycling, reuse and refurbishment of products and materials. Technological enthusiasts such as Kelly [101] argue that the "technium" is now a self-perpetuating organism that values efficiency, diversity, freedom, and "evolvability." The technium will only survive and prosper as long as humans and other Earth life survive and prosper. Thus, it is in the self-interest of the evolving technium to be as environmentally-friendly as possible. For better or worse, the technium offers potential solutions to many vexing environmental problems that threaten species survival. For example, the technium offers the possibility of managing Earth's climate by releasing tons of sulfur into the atmosphere or iron into the oceans to counter global warming [92].

Moore's Law of doubling processor power every two years continues to be at work [102] and leads to faster computers that can handle more and more processes. Artificial intelligence is emerging as a function of faster processors and more sophisticated software and means that computers and robots could someday help us even more with these problems. Ideas move faster as a function of the Internet, and especially as a function of social networking, which leads to opportunities to advance ideas and cooperation [103]. Some researchers suggest that we will share more and more ideas and objects as a function of technologies for coordinating and for creating, which leads to further material and energy efficiencies [104]. Thus, at the other end of the spectrum, the technium may allow humans to live in online virtual environments that are satisfying and enriching while also simultaneously leading to substantial reductions in the consumption of material goods and services in the "real" world [105]. Increased use of virtual reality may lead to additional human confusion between virtual and actual 
reality, though it is also possible to constantly remind the user that this is virtual equipment [106] or offer more training and therapy.

Technologies can also directly improve environmental and species protection. One interesting example of technological evolution is the use of technology to monitor conservation strategies in two of Trinidad's protected wetlands. Using remote sensing, scientists can immediately detect increases in human activity and changes to the environment [107]. However, instead of monitoring conservation strategies in Trinidad, it may be more effective to set up the cultural and ecological circumstances so that surveillance is unnecessary. For example, increases in the Rwandan gorilla population led to an increase in tourism, which led to an overall increase in much-needed revenue for the nation; increased the amount of money available for conservation; and increased the number of people who are protecting the environment for the gorillas [108].

Technological change must be well thought out. Humans have produced almost 400 herbicide-resistant biotypes weeds such as rigid ryegrass, wild oat, and redroot pigweed [109]. Genetically modified organism (GMO) crops are available and are supposed to lead to cheaper soybeans, corn, rice, and others, yet food prices continue to rise even for the poor [110]. Relying on technological solutions in the future at the expense of solutions in the present can yield its own problems such as runaway technology, new problems we did not plan for, and new problems that cannot be addressed by the solutions at hand.

Challenges of technological evolution. The time frame challenge to technological evolution is coming up with enough technological solutions, vetting them for effectiveness, considering unintended consequences, justifying ethical considerations, legislating (when necessary), funding them, and implementing them in time. For example, Hallegatte suggests that scientists and technologists may not produce a unified climate model in time to make the necessary infrastructure adjustments. He argues that we should adapt by planning future infrastructure that is resilient to a range of climate and extreme event conditions [111].

We also have to find ways to embrace and leverage our cultural tendency to keep doing what we have always done rather than adopt technological evolution. The concept of use-inspired basic research is relevant for these contexts [112] though we argue that the true challenge to technological evolution is a function of human inventiveness, ability to get things done, and willingness to change.

\section{Discussion and Conclusions}

Is there a way to win the race for evolutionary success? What does it look like when evolution goes right? In what ways can evolutionary successes disrupt the paths towards massive species extinction? Humans tend to focus on ways that everything can go awry. Here, we detail evolutionary successes as well as promising research in related areas that suggest that evolution writ large could go right.

One implication of these evolutions is the opportunity to combine two or more evolutions for an even bigger evolutionary benefit. Technology turns out to offer several opportunities for ecological and biological evolution such as nanotechnology applications for automation and machine replication that could protect species while also improving human productivity. Another implication is the interaction between the components for extinction - energy consumption, land development, economic 
production, climate change, etc.- and the cultural, regulatory, ecological, and technological evolutions we describe. The overall effects of this system must be considered strategically and holistically.

We propose several opportunities for future research. First, researchers could study these evolutions individually and in combination. Second, there are opportunities to map the various paths towards extinction and specify the ways in which the specific opportunities and examples we outline here could be the disruptors. We see tremendous evolutionary successes and the potential for far more given the opportunities and examples we detailed. Third, we chose to write this paper from a first world perspective, which means that future researchers must do additional work to address third world realities such as rising food prices, water shortages, and famine. Fourth, analysis and research are necessary to figure out the mix of work to be done and the time frame in which it must be completed to take advantage of the positive trends we have outlined.

Rather than using these positive stories to become complacent about what is happening, deciding that additional work and urgency are unnecessary, our challenge is to do enough of the right things at the right time. Page suggests we implement a principal from jujitsu:

"We must turn the awesome forces of freedom, self interest, and ambition against their current wasteful incarnation. We can, and should, continue to aspire, to dream, to achieve, to engage in the pursuit of happiness, meaning, and knowledge, but we should be encouraged to do so without using so much stuff or by using stuff that is renewable and recyclable" [113].

We hope this article will encourage discussion as well as prompt, effective, and sustained action so that we start implementing solutions faster than new problems arise. Imagine what could be possible if these potential evolutions informed our future choices: We could win the race for evolutionary success.

\section{References}

1. Carrasco, M.A.; Barnosky, A.D.; Graham, R.W. Quantifying the extent of North American mammal extinction relative to the pre-anthropogenic baseline. PLoS One 2009, 4, e8331.

2. Diamond, J. Guns, Germs, and Steel: The Fates of Human Societies; W.W. Norton \& Company, Inc.: New York, NY, USA, 1997.

3. Levin, D. Hybridization and extinction-In protecting rare species, conservationists should consider the dangers of interbreeding which compound more well known threats to wildlife. Am. Sci. 2002, 90, 254-261.

4. Ruddimann, W.F. Plows, Plagues, and Petroleum: How Humans Took Control of Climate; Princeton University Press: Princeton, NJ, USA, 2005.

5. Bellard, C.; Bertelsmeier, C.; Leadley, P.; Thuiller, W.; Courchamp, F. Impacts of climate change on the future of biodiversity. Ecol. Lett. 2012, 15, 365-377.

6. Elewa, A.M.T.; Joseph, R. The history, origins, and causes of mass extinctions. J. Cosmol. 2009, 2, 201-220.

7. Barnosky, A.D.; Matzke, N.; Tomiya, S.; Wogan, G.O.; Swartz, B.; Quental, T.B.; Marshall, C.; McGuire, J.L.; Lindsey, E.L.; Maguire, K.C.; et al. Has the Earth's sixth mass extinction already arrived? Nature 2011, 471, 51-57. 
8. Bell, W. Why Should We Care about Future Generations? In: Why Future Generations Now?; Inst. for the Integrated Study of Future Generations: Kitaku, Osaka, Japan, 1994; pp. 40-62.

9. MacLean, D. Introduction to Conflicting Views on a Neutrality Criterion for Radioactive Waste Management. In University of Maryland, College Park, Center for Philosophy and Public Policy; Bodde, D., Cochran, T., Eds.; University of Maryland: College Park, MD, USA, 1981.

10. Tonn, B.E. Preventing the Next Mass Extinction: Ethical Obligations. J. Cosmol. 2009, 2, 334-343.

11. Weiss, E.B. In fairness to future generations. Environ. Dev. Econ. 1990, 32, 6-31.

12. Pimm, S.; Raven, P.; Peterson, A.; Şekercioğlu, Ç. Human impacts on the rates of recent, present, and future bird extinctions. Proc. Natl. Acad. Sci. USA 2006, 103, 10941-10946.

13. Diamond, J. Collapse: How Societies Choose to Fail or Succeed: Revised Edition; Penguin Books: New York, NY, USA, 2011.

14. Tonn, B.E.; MacGregor, D. A singular chain of events. Futures 2009, 41, 706-714.

15. Page, S.E. Are we collapsing? A review of jared diamond's collapse: How societies choose to fail or succeed. J. Econ. Lit. 2005, 43, 1051.

16. Carpenter, P.; Bishop, P. The seventh mass extinction: Human-caused events contribute to a fatal consequence. Futures 2009, 41, 715-722.

17. Goux-Baudiment, F. Tomorrow will die. Futures 2009, 41, 746-753.

18. Jones, C. Gaia bites back: Accelerated warming. Futures 2009, 41, 723-730.

19. Lopes, T.; Chermack, T.; Demers, D.; Kari, M.; Kasshanna, B.; Payne, T. Human extinction scenario frameworks. Futures 2009, 41, 731-737.

20. Morgan, D. World on fire: Two scenarios of the destruction of human civilization and possible extinction of the human race. Futures 2009, 41, 683-693.

21. Tonn, B.E.; MacGregor, D. A singular chain of events. Futures 2009, 41, 706-714.

22. Tonn, B.E. A methodology for organizing and quantifying the results of environmental scanning exercises. Technol. Forecast. Soc. 2008, 75, 595-609.

23. Slaughter, R. The foresight principle. Futures 1990, 22, 801-819.

24. Boniecki, G. What are the limits to man's time and space perspectives? Toward a definition of a realistic planning horizon. Tech. Forecast. Soc. Chang. 1980, 17, 161-175.

25. Tonn, B.E.; Conrad, F.; Hemrick, A. Cognitive representations of the future: Survey results. Futures 2006, 38, 810-829.

26. National Research Council. Technical Bases for Yucca Mountain Standards; National Academy Press: Washington, DC, USA, 1995.

27. Kim, J.-S.; Kwon, S.-K.; Sanchez, M.; Cho, G.-C. Geological storage of high level nuclear waste. KSCE J. Civ. Eng. 2011, 15, 721-737.

28. Forbes, A.A.; Krimmel, B.A. Evolution is change in the inherited traits of a population through successive generations. Nat. Educ. Knowl. 2010, 1, 6.

29. Vitousek, P.M.; Mooney, H.A.; Lubchenco, J.; Melilo, J.M. Human domination of earth's ecosystem. Science 1997, 277, 494-499.

30. Mace, G.M.; Collen, B.; Fuller, R.A.; Boakes, E.H. Population and geographic range dynamics: Implications for conservation planning. Philos. T. Roy. Soc. B 2010, 365, 3743-3751. 
31. Davis, S.J.; Caldeira, K.; Matthews, H.D. Future $\mathrm{CO}_{2}$ emissions and climate change from existing energy infrastructure. Science 2010, 329, 1330-1333.

32. Allendorf, F.W.; England, P.R.; Luikart, G.; Ritchie, P.A.; Ryman, N. Genetic effects of harvest on wild animal populations. Trends Ecol. Evol. 2008, 23, 327-337.

33. United Nations. United Nations. Department of Economic and Social Affairs. Available online: http://esa.un.org/unpd/wup/index.htm (accessed on 25 July 2012).

34. McCulloch, A. Housing density as a predictor of neighborhood satisfaction among families with young children in urban England. Pop. Space Place 2012, 18, 85-99.

35. Dave, S. Neighbourhood density and social sustainability in cities of developing countries. Sustain. Dev. 2011, 19, 189-205.

36. Global Ecovillage Network. Ecovillage Directory Search Results. Available online: http:/gen.ecovillage.org/iservices/index.html (accessed 28 June 2012).

37. Global Ecovillage Network. About GEN. Available online: http://gen.ecovillage.org/ index.php?option=com_content\&view $=$ article \&id=91\&Itemid=234 (accessed on 25 July 2012).

38. Bongaarts, J. Human population growth and the demographic transition. Philos. T. Roy. Soc. B 2009, 364, 2985-2990.

39. Kempton, W.; Boster, J.S.; Hartley, J.A. Environmental Values in American Culture; The MIT Press: Cambridge, MA, USA, 1995.

40. Lutz, W.; Sanderson, W.; Scherbov, S. The coming acceleration of global population ageing. Nature 2008, 451, 716-719.

41. Brooks, T.M.; Mittermeier, R.A.; Mittermeier, C.G.; da Fonseca, G.A.B.; Rylands, A.B.; Konstant, W.R.; Flick, P.; Pilgrim, J.; Oldfield, S.; Magin, G. Habitat loss and extinction in the hotspots of biodiversity. Conserv. Biol. 2002, 16, 909-923.

42. Cincotta, R.P.; Wisnewski, J.; Engelman, R. Human population in biodiversity hotspots. Nature 2000, 404, 990-992.

43. Marglin, S. The culture of economics. Development 2009, 52, 292-297.

44. Tonn, B.E. Determinants of futures-oriented environmental policies: A multi-country analysis. Futures 2007, 39, 773-789.

45. Van den Hove, S. A rationale for science-policy interfaces. Futures 2007, 39, 807-826.

46. Kaswamila, A.L.; Songorwa, A.N. Participatory land-use planning and conservation in northern tanzania rangelands. Afr. J. Ecol. 2009, 47, 128-134.

47. Plater, Z.J.B. Tiny fish/big battle: 30 years after TVA and the snail darter clashed, the case still echoes in caselaw, politics and popular culture. Tenn. Bar. J. 2008, 44, 14-42.

48. Zelkowitz, R. Pacific Northwest Sea bird may lose 'threatened' status. Science 2008, 322, doi:10.1126/science.322.5899.177a.

49. Tonn, B.E. The intergovernmental panel for climate change: A global scale transformative initiative. Futures 2007, 39, 614-618.

50. Füssel, H.-M. An updated assessment of the risks from climate change based on research published since the IPCC fourth assessment report. Clim. Chang. 2009, 97, 469-482.

51. Hulme, M.; Mahony, M. Climate change: What do we know about the IPCC? Prog. Phys. Geogr. 2010, 34, 705-718. 
52. Connery, K. Biodiversity and urban design: Seeking an integrated solution. J. Green. Build. 2009, 4, 23-38.

53. Perrings, C.; Duraiappah, A.; Larigauderie, A.; Mooney, H. The biodiversity and ecosystem services science-policy interface. Science 2011, 331, 1139-1140.

54. United Nations Educational, Scientific and Cultural Organization. Ecological Sciences for Sustainable Development: Biosphere Reserves-Learning Sites for Sustainable Development. Available online: http:/www.unesco.org/new/en/natural-sciences/environment/ecological-sciences/ biosphere-reserves/ (accessed on 25 July 2012).

55. Weerawardena, J.; McDonald, R.E.; Mort, G.S. Sustainability of nonprofit organizations: An empirical investigation. J. World. Bus. 2010, 45, 346-356.

56. Hawken, P. Blessed Unrest: How the Largest Movement in the World Came into Being and Why No One Saw It Coming; Viking: New York, NY, USA, 2007.

57. International Organization for Standardization. How ISO Standards Help: GHG Schemes Addressing Climate Change. Available online: http://www.iso.org/iso/ghg_climate-change.pdf (accessed on 25 July 2012).

58. Vandenbergh, M.P.; Dietz, T.; Stern, P.C. Time to try Carbon labelling. Nat. Clim. Chang. 2011, $1,4-6$.

59. Scholz, J.T.; Wang, C.-L. Cooptation or transformation? Local policy networks and federal regulatory enforcement. Am. J. Polit. Sci. 2006, 50, 81-97.

60. Lankau, R.; Jorgensen, P.S.; Harris, D.J.; Sih, A. Incorporating evolutionary principles into environmental management and policy. Evol. Appl. 2011, 4, 315-325.

61. Iwamura, T.; Wilson, K.A.; Venter, O.; Possingham, H.P. A climatic stability approach to prioritizing global conservation investments. PLoS One 2010, 5, e15103.

62. Henson, A.; Williams, D.; Dupain, J.; Gichohi, H.; Muruthi, P. The heartland conservation process: Enhancing biodiversity conservation and livelihoods through landscape-scale conservation planning in Africa. Oryx 2009, 43, 508-519.

63. Shackleton, C.M.; Cundill, G.; Knight, A.T. Beyond just research: Experiences from southern africa in developing social learning partnerships for resource conservation initiatives. Biotropica 2009, 41, 563-570.

64. Wheeler, M.; Chambers, F.M.J.; Sims-Castley, R.; Cowling, R.M.; Schoeman, D. From beans to breams: How participatory workshops can contribute to marine conservation planning. Afr. J. Mar. Sci. 2008, 30, 475-487.

65. Tversky, A.; Kahnemann, D. Availability: A heuristic for judging frequency and probability. Cogn. Psychol. 1973, 5, 207-233.

66. Bloom, P.; Weisberg, D.S. Childhood origins of adult resistance to science. Science 2007, 316, 996-997.

67. Oreskes, N.; Conway, E.M.; Shindell, M. From Chicken Little to Dr. Pangloss: William Nierenberg, global warming, and the social deconstruction of scientific knowledge. Hist. Stud. Nat. Sci. 2008, 38, 109-152.

68. Sharot, T. The optimism bias. Curr. Biol. 2011, 21, 941-945. 
69. Lee, J.J. Update: Revised North Carolina sea level rise bill goes to the governor. ScienceInsider, 3 July 2012. Available online: http://news.sciencemag.org/scienceinsider/2012/07/updaterevised-north-carolina-se.html (accessed on 23 July 2012).

70. Intergovernmental Panel on Climate Change. Managing the Risks of Extreme Events and Disasters to Advance Climate Change Adaptation: Special Report of the Intergovernmental Panel on Climate Change; Cambridge University Press: New York, NY, USA, 2012.

71. Van Aalst, M.K. The impacts of climate change on the risk of natural disasters. Disasters 2006, 30, 5-18.

72. McKinnon, J.S.; Taylor, E.B. Biodiversity: Species choked and blended. Nature 2012, 482, 313-314.

73. Thuiller, W. Biodiversity: Climate change and the ecologist. Nature 2007, 448, 550-552.

74. Gibbs, H.K.; Ruesch, A.S.; Achard, F.; Clayton, M.K.; Holmgren, P.; Ramankutty, N.; Foley, J.A. Tropical forests were the primary sources of new agricultural land in the 1980s and 1990s. Proc. Natl. Acad. Sci. USA 2010, 107, 16732-16737.

75. McKee, J.K. Contemporary mass extinction and the human population imperative. J. Cosmol. 2009, 2, 300-308.

76 Lambertucci, S.A.; Speziale, K.L. Protecting invaders for profit. Science 2011, 332, doi:10.1126/science.332.6025.35-a.

77. North, A.; Pennanen, J.; Ovaskainen, O.; Laine, A.L. Local adaptation in a changing world: The roles of gene-flow, mutation, and sexual reproduction. Evolution 2011, 65, 79-89.

78. Morens, D.M.; Folkers, G.K.; Fauci, A.S. The challenge of emerging and re-emerging infectious diseases. Nature 2004, 430, 242-249.

79. Neu, H.C. The crisis in antibiotic resistance. Science 1992, 257, 1064-1072.

80. Metcalf, R.L. Insect resistance to insecticides. Pestic. Sci. 1989, 26, 333-358.

81. Tuomainen, U.; Candolin, U. Behavioural responses to human-induced environmental change. Biol. Rev. 2010, 86, 1-18.

82. Shimada, M.; Ishii, Y.; Shibao, H. Rapid adaptation: A new dimension for evolutionary perspectives in ecology. Popul. Ecol. 2010, 52, 5-14.

83. Gould, S.J.; Eldredge, N. Punctuated equilibrium comes of age. Nature 1993, 366, 223-227.

84. Hendry, A.P.; Kinnison, M.T.; Heino, M.; Day, T.; Smith, T.B.; Fitt, G.; Bergstrom, C.T.; Oakeshott, J.; Jorgesnsen, P.S.; Zalucki, M.P.; et al. Evolutionary principles and their practical application. Evol. Appl. 2011, 4, 171.

85. Sih, A.; Ferrari, M.C.O.; Harris, D.J. Evolution and behavioural responses to human-induced rapid environmental change. Evol. Appl. 2011, 4, 367-387.

86. Matesanz, A.U.; Gianoli, E.; Valladares, F. Global change and the evolution of phenotypic plasticity in plants. Ann. N. Y. Acad. Sci. 2010, 1206, 35-55.

87. Barton, B.T. Local adaptation to temperature conserves top-down control in a grassland food web. Philos. T. Roy. Soc. B 2011, doi:10.1098/rspb.2011.0030.

88. Thomas, C.D. Translocation of species, climate change, and the end of trying to recreate past ecological communities. Trends Ecol. Evol. 2011, 26, 1-6.

89. Sgro, C.M.; Lowe, A.J.; Hoffmann, A.A. Building evolutionary resilience for conserving biodiversity under climate change. Evol. Appl. 2011, 4, 326-337. 
90. Dawson, T.P.; Jackson, S.T.; House, J.I.; Prentice, I.C.; Mace, G.M. Beyond predictions: Biodiversity conservation in a changing climate. Science 2011, 332, 53-58.

91. Carson, R.T. Silent Spring; Houghton Mifflin: New York, NY, USA, 1962.

92. Kintisch, E. Hack the Planet: Science's Best Hope-Or Worst Nightmare-For Averting Catastrophe; Wiley: New York, NY, USA, 2010.

93. Robock, A. 20 reasons why geoengineering may be a bad idea. Bull. At. Sci. 2008, doi:10.2968/064002006.

94. Virgoe, J. International governance of a possible geoengineering intervention to combat climate change. Clim. Chang. 2009, 95, 103-119.

95. Arthur, W.B. The Nature of Technology: What It Is and How It Evolves; Free Press: New York, NY, USA, 2009.

96. Roco, M.C.; Bainbridge, W.S. Converging Technologies for Improving Human Performance: Nanotechnology, Biotechnology, Information Technology and Cognitive Science; Kluwer Academic Publishers: Dordrecht, The Netherlands, 2003.

97. National Science and Technology Council. National Nanotechnology Initiative: Strategic Plan; National Science and Technology Council Committee on Technology Subcommittee on Nanoscale Science, Engineering, and Technology: Washington, DC, USA, 2011.

98. Roco, M.C.; Mirkin, C.A.; Hersam, M.C. Nanotechnology Research Directions for Societal Needs in 2020: Retrospective and Outlook; Springer: Berlin, Germany, and New York, USA, 2011.

99. Kurzweil, R. The Singularity Is Near: When Humans Transcend Biology; Viking Adult: New York, NY, USA, 2005.

100. Public Broadcasting Service. Making Stuff: Public Broadcasting Service Videos. Available online: http://www.pbs.org/wgbh/nova/tech/making-stuff.html (accessed on 25 July 2012).

101. Kelly, K. What Technology Wants; Viking: New York, NY, USA, 2010.

102. Cavin, R.K.; Lugli, P.; Zhirnov, V.V. Science and engineering beyond Moore'S law. Proc. IEEE 2012, 100, 1720-1749.

103. Ohtsuki, H.; Huert, C.; Lieberman, E.; Nowak, M.A. A simple rule for the evolution of cooperation on graphs and social networks. Nature 2006, 441, 502-505.

104. Gansky, L. The mesh: Why the future of business is sharing. Portfolio Penguin: New York, NY, USA, 2010.

105. Bainbridge, W.S. Virtual Sustainability. Sustainability 2010, 2, 3195-3210.

106. Fraser, M.; Glover, T.; Vaghi, I.; Benford, S.; Greenhalgh, C.; Hindmarsh, J.; Heath, C. Revealing the Realities of Collaborative Virtual Reality. In Proceedings of the Third International Conference on Collaborative Virtual Environments, San Francisco, CA, USA, 10-12 September 2000; pp. 29-37.

107. Gibbes, C.; Southworth, J.; Keys, E. Wetland conservation: Change and fragmentation in Trinidad's protected areas. Geoforum 2009, 40, 91-104.

108. Stainback, G.A.; Masozera, M. Payment for ecosystem services and poverty reduction in Rwanda. J. Sustain. Dev. Afr. 2010, 12, 122-139.

109. Weedscience.com. International Survey of Herbicide Resistant Weeds. Available online: http://www.weedscience.com (accessed on 28 June 2012). 
110. Toye, J. Development with dearer food: Can the invisible hand guide us? J. Int. Dev. 2009, 21, 757-764.

111. Hallegatte, S. Strategies to adapt to an uncertain climate change. Glob. Environ. Chang. 2009, 19, 240-247.

112. Clark, W.C. Sustainability science: A room of its own. Proc. Natl. Acad. Sci. USA 2007, 104, 1737-1738.

113. Page, S.E. Are we collapsing? A review of Jared Diamond's Collapse: How societies choose to fail or succeed. J. Econ. Lit. 2005, 43, 1062.

(C) 2012 by the authors; licensee MDPI, Basel, Switzerland. This article is an open access article distributed under the terms and conditions of the Creative Commons Attribution license (http://creativecommons.org/licenses/by/3.0/). 